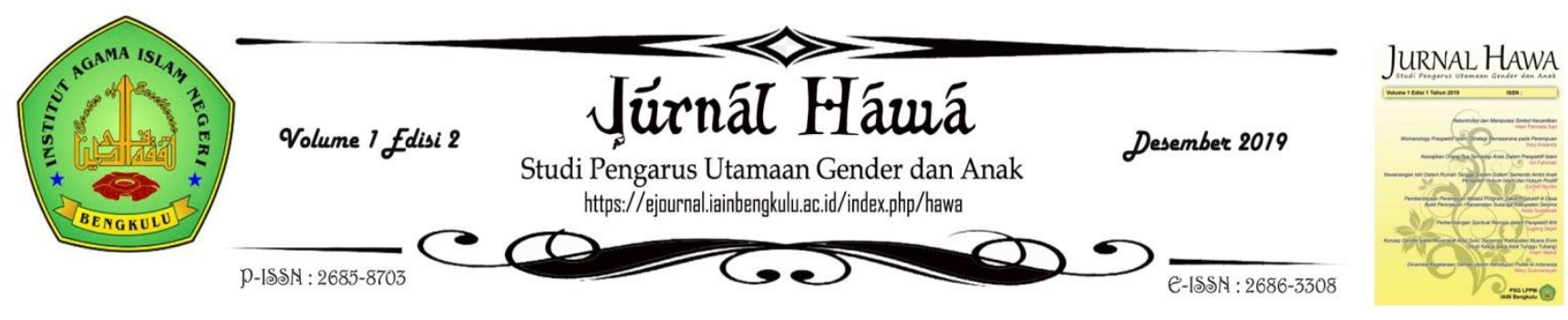

\title{
Eksistensi Dispensasi Perkawinan terhadap Pelaksanaan Perlindungan Anak Di Indonesia
}

\author{
M. Abdussalam Hizbullah \\ iboboel@gmail.com \\ KUA Kaur
}

\section{Info Artikel}

\author{
Diterima: Oktober \\ 2019
}

Disetujui: Oktober 2019

\section{Dipublikasikan:}

Desember 2019

\section{Reyword}

Child Protection and Marriage Dispensation

\section{Kata Kunci}

Perlindungan Anak dan Dispensasi Perkawinan.

\section{Abstract}

Abstract: The Existence of Marriage Dispensation for the Implementation of Child Protection in Indonesia. Indonesia has guaranteed the implementation of child protection very well. Nevertheless, prevention of child marriage as a part of child protection cannot be done in full with the dispensation of child marriage. In fact, after conducting research by various groups on the implementation of marriage dispensation, found a lot of adverse effects from its implementation. This of course supports the prevention of marriage at the age of children in the context of implementing child protection in Indonesia. Therefore, a study is needed to determine whether the implementation of marriage dispensation can degrade the implementation of child protection in Indonesia. This research was conducted by examining the regulations contained in Law number 35 of 2014 concerning Marriage and Law number 1 of 1974 concerning Marriage. The method used is descriptive qualitative and judicative methods with literature review. The data in this research was obtained from Law number 35 of 2014 concerning Marriage and Law number 1 of 1974 concerning Marriage, as well as other literature that discusses child protection and marriage dispensation. To analyze the data obtained, researchers used the Miles and Huberman analysis model. After analyzing the data that has been obtained, a conclusion is obtained which shows that the implementation of marriage dispensation cannot degrade the implementation of child protection in Indonesia. In other words, child protection in Indonesia should be given more attention to ensure that every child can obtain their rights in full. While the rules regarding the implementation of marriage dispensations must be further studied regarding their existence in protecting children in Indonesia, so that their implementation does not conflict with the implementation of child protection in Indonesia.

\section{Abstrak}

Eksistensi Dispensasi Perkawinan terhadap Pelaksanaan Perlindungan Anak di Indonesia. Indonesia telah menjamin pelaksanaan perlindungan anak dengan sangat baik. Kendati demikian, pencegahan perkawinan anak sebagai salah satu bagian dari perlindungan anak tidak dapat dilakukan secara utuh dengan adanya dispensasi perkawinan usia anak. Padahal, setelah dilakukan penelitian oleh berbagai kalangan tentang pelaksanaan dispensasi perkawinan, ditemukan banyak sekali dampak buruk dari pelaksanaannya. Hal tersebut tentu saja mendukung pencegahan perkawinan di usia anak dalam rangka pelaksanaan perlindungan anak di Indonesia. Oleh karena itu, perlulah dilakukan pengkajian untuk mengetahui apakah pelaksanaan dispensasi perkawinan dapat mendegradasi pelaksanaan perlindungan anak di Indonesia. Penelitian ini dilakukan dengan mengkaji peraturan yang termuat dalam Undang-Undang nomor 35 tahun 2014 tentang Perkawinan dan Undang-Undang nomor 1 tahun 1974 tentang Perkawinan. Metode yang digunakan adalah metode kualitatif desrkriptif dan yudikatif dengan kajian pustaka. Data-data dalam penilitan ini diperoleh dari Undang-Undang nomor 35 tahun 2014 tentang Perkawinan dan Undang-Undang nomor 1 tahun 1974 tentang Perkawinan, serta literatur lain yang membahas mengenai perlindungan anak dan dispensasi perkawinan. Untuk menganalisis data yang diperoleh, peneliti menggunakan model analisis Miles dan Huberman. Setelah menganalisisi data-data yang telah diperoleh, didapatilah sebuah kesimpulan yang menunjukkan bahwa pelaksanaan dispensasi perkawinan tidak dapat mendegradasikan pelaksanaan perlindungan anak di Indonesia. Dengan kata lain, perlindungan anak di Indonesia sudah seyogyanya lebih diperhatikan untuk memastikan bahwa setiap anak dapat memperoleh hak-haknya secara utuh. Sedangkan aturan mengenai pelaksanaan dispensasi perkawinan harus dikaji lebih lanjut mengenai eksistensinya terhadap perlindungan anak di Indonesia, agar pelaksanaannya tidak berbenturan dengan pelaksanaan perlindungan anak di Indonesia. 


\section{Pendahuluan}

Ketika mengacu pada Pasal 28 B ayat (2) UndangUndang Dasar Negara Republik Indonesia tahun 1945, kita akan mendapati cita-cita bangsa dalam melaksanakan perlindungan anak. Pada pasal tersebut dinyatakan bahwa setiap anak berhak atas kelangsungan hidup tumbuh dan berkembang, serta berhak atas perlindungan dari kekerasan dan diskriminasi. Hal tersebut menunjukkan bahwa ada amanat besar yang harus dilakukan untuk memasikan terlaksananya perlindungan anak di Indonesia.

Banyak sekali langkah yang telah diambil oleh pemerintah untuk memastikan terlaksananya perlindungan anak di Indonesia. Mulai dari pembentukan lembaga perlindungan anak, hingga penetapan peraturan perundangundangan tentang pelaksanaan perlindungan anak di Indonesia. Undang-undang perlindungan anak yang terbaru adalah Undang-Undang nomor 35 tahun 2014 tentang Perlindungan Anak sebagai perubahan undangundang sebelumnnya, yaitu Undang-Undang nomor 23 tahun 2002 tentang Perlindungan Anak.
Dalam Undang-Undang nomor 35 tahun 2014 tentang Perlindungan Anak, yang dimaksud dengan perlindungan anak adalah segala kegiatan untuk menjamin dan melindungi anak dan hak-haknya agar dapat hidup, tumbuh, berkembang, dan berpartisipasi, secara optimal sesuai dengan harkat dan martabat kemanusiaan, serta mendapat perlindungan dari kekerasan dan diskriminasi.

Menurut Ahmad Kamil (Rini Fitriani: 2016), Perlindungan Anak adalah bentuk pertanggungjawaban orang tua, keluarga, masyarakat, pemerintah dan negara dalam bentuk rangkaian kegiatan yang dilaksanakan secara continual demi terlindunginya hak-hak anak.

Menurut Siregar (Layyin Mahfiana: 2013), aspek perlindungan anak lebih ditekankan pada hak hak anak bukan kepada kewajiban anak, karena anak secara hukum, anak belum dibebani kewajiban dan tidak dituntut pertanggungjawaban.

Dari beberapa definisi tentang perlindungan anak di atas, pada pokoknya, 
perlindungan anak adalah pemenuhan hak-hak anak secara menyeluruh, baik dari sisi kehidupan, pendidikan, dan perlindungan atas sesuatu yang membahayakannya yang harus diberikan oleh orang tua, keluarga, masyarakat maupun pemerintah.

Pemenuhan perlindungan anak adalah meletakkan hak anak ke dalam status sosial anak dalam kehidupan masyarakat, sebagai bentuk perlindungan terhadap kepentingankepentingan anak yang mengalami masalah sosial. Perlindungan hak asasi anak dapat diberikan dengan cara yang sistematis melalui serangkaian program, stimulasi, latihan, pendidikan, bimbingan keagamaan, permaianan dan dapat juga diberikan melalui bantuan hukum yang dinamakan advokasi dan hukum perlindungan anak (Layyin Mahfiana: 2013).

Hingga kini, sudah banyak aturan perundang-undangan yang mengatur tentang perlindungan anak di Indonesia. Meski demikian, masih ada aturan hukum yang masih tumpang tindih dengan aturan hukum lainnya. Misalnya aturan dalam Undang-Undang nomor 35 tahun 2014 tentang perlindungan anak dan Undang-Undang nomor 1 tahun 1974 tentang Perkawinan.

Berdasarkan Pasal 26 ayat (1) butir c Undang-Undang Nomor 35 tahun 2014 tentang Perlindungan Anak,orang tua berkewajiban untuk mencegah terjadinya perkawinan di usia anak. Atas ketentuan tersebut, pelaksanaan perkawinan pada usia anak sebisa mungkin harus dicegah. Tetapi, pencegahan perkawinan di usia anak menjadi sulit dilaksanakan dengan adanya dispensasi perkawin-an di Pengadilan Agama.

Secara umum, dispensasi perkawinan adalah permohonan izin yang diajukan ke Pengadilan Agama untuk dapat melaksanakan perkawinan yang akan dilaksanakan oleh pasangan yang salah satu atau keduanya belum mencapai usia yang telah ditetapkan oleh Undang-Undang Nomor 1 tahun 1974 tentang Perkawinan.

Menurut Setiasih (2017), dispensasi perkawinan adalah suatu kelonggaran yang diberikan oleh Pengadilan kepada calon suami-isteri yang belum mencapai usia untuk melaksanakan perkawinan. 
Sedangkan menurut Idayanti (2014), dispensasi usia perkawinan merupakan pengurangan terhadap standar normatif yang diatur oleh Undang-Undang mengenai batas minimal usia perkawinan bagi seseorang yang akan melangsungkan perkawinan.

Pada intinya, dispensasi perkawinan adalah langkah yang dapat diambil oleh anak-anak yang ingin melaksanakan perkawinan. Pelaksanaan dispenasi perkawinan ini didasari oleh ketentuan pada Pasal 7 ayat (2) Undang-Undang Nomor 01 tahun 1974 tentang Perkawinan, bahwa pelaksanaan perkawinanpada usia di bawah umur (usia anak) diperbolehkan melalui permohonan dispensasi perkawinan ke Pengadilan Agama.

Jika melihat adanya kebolehan melaksanakan perkawinan di usia anak, hal tersebut tentu menimbulkan ketidakpastian hukum pada pelaksanaan perlindungan anak di Indonesia yang justru mencoba untuk mencegah terjadinya perkawinan anak di Indonesia. Oleh karena itu, perlu dilakukan kajian terhadap dispensasi perkawinan mengingat adanya beberapa benturan hukum antara pelaksanaan perlindungan anak dengan dispensasi perkawinan.

Disamping itu, peneliti juga menemukan beberapa dampak negatif dari pelaksanaan perkawinan anak pasca adanya dispensasi perkawinan, mulai dari perceraian dini, ekonomi, sosial, psikis hingga dampak kesehatan. Hal tersebut tentu perlu menjadi perhatian atas pelaksanaan dispensasi perkawinan usia anak di Indonesia.

Atas benturan yang terjadi pada pelaksanaan perlindungan anak di Indonesia ketika bersinggungan dengan pelaksanaan perkawinan pasca adanya dispensasi perkawinan, peneliti menganggap perlu untuk mengkaji lebih lanjut mengenai hal itu agar pelaksanaan perlindungan anak di Indonesia dapat dilaksanakan dengan baik. Dari alasan tersebut, peneliti merumuskannya pada sebuah rumusan masalah, yaitu apakah dispensasi perkawinan dapat mendegradasikan pelaksanaan perlindungan anak?

Penelitian ini dilakukan dengan menggunakan pendekatan kualitatif dengan 
jenis penelitian deskriptif dan yudikatif.

Penelitian ini dilakukan dengan kajian pustaka, dimana peneliti mengumpulkan data penelitian dari literatur-literatur yang telah ada. Data primer dalam penelitian ini bersumber dari literatur-literatur hukum mengenai perlindungan anak dan dispensasi perkawinan. Sedangkan data sekunder bersumber dari buku, jurnal, dan penelitian yang berkaitan dengan pelaksanaan perlindungan anak dan dispensasi perkawinan.

Untuk menganalisis data, penelitian ini akan menggunakan analisis data model interaktif Milles dan Huberman (1992: 90) dengan tiga proses penelitian. Pertama, reduksi data, yaitu proses memilih memfokuskan, menyederhanakan, dan mengabtraksikan data dari berbagai sumber data terkait perlindungan anak dan dispensasi perkawinan.

Kedua, Penyajian data, yaitu menyusun data dan menyajikan data penelitian terkait masalah yang menjadi topik penelitian dengan baik sehingga lebih mudah dipahami. Ketiga, mengambil

kesimpulan/verifikasi, yaitu proses pengambilan kesimpulan atas penelitian yang dilakukan.

\section{Pembahasan}

\section{A. Urgensi Perlindungan Anak di Indonesia}

Perlindungan anak di era globalisasi sangat dibutuhkan demi kelangsungan generasi muda di masa depan. Realita yang terjadi di masyarakat, meskipun Indonesia secara umum telah memberikan perlindungan terhadap anak, tetapi dalam pelaksanaannya, masih berlangsung berbagai eksploitasi anak yang sangat memprihatinkan baik yang dilakukan oleh negara, corporate, maupun non-state-actors (Mafiana: 2013).

Sebelum terbentuknya undang-undang perlindungan anak, aturan perundangundangan mengenai hak-hak anak diatur pada UndangUndang Nomor 39 Tahun 1999 tentang Hak Asasi Manusia. Meski demikian pembentukan undang-undang perlindungan anak tetap diperlukan sebagai bagian dari kegiatan pembangunan nasional dalam memajukan kehidupan berbangsa dan bernegara (undang-undang perlindungan anak: 2002). 
Saat Undang-Undang Nomor 23 tahun 2002 tentang Perlindungan Anak disahkan sebagai peraturan perundangundangan di Indonesia, salah satu tujuan ditetapkan undangundang tersebut adalah untuk menunjukkan bahwa Negara Kesatuan Republik Indonesia menjamin kesejahteraan tiap-tiap warga negaranya termasuk perlindungan terhadap hak-hak anak yang merupakan hak asasi manusia, yang dalam dirinya melekat harkat dan martabat sebagai manusia seutuhnya (Tedy Sudrajat: 2011).

Menurut Ahmad Kamil, Perlindungan Anak adalah bentuk pertanggung jawaban orang tua, keluarga, masyarakat, pemerintah dan negara berupa rangkaian kegiatan yang dilaksanakan secara continual demi terlindunginya hak-hak anak (Ahmad Kamil: 2008). Untuk itu, maka perlu dilakukan pengawasan ekstra terhadap anak baik secara pribadi maupun sebagai bagian dari masyarakat. Hal tersebut ditujukan untuk melindungi hak-hak anak serta mencegah masuknya pengaruh eksternal yang negatif yang dapat mengganggu tumbuh kembang anak (Hardjono, 2007).
Untuk melindungi hakhak anak, maka diperlukan peraturan perundang-undangan untuk menjunjung tinggi harkat, martabat, dan hak-haknya sebagai manusia. Karena hak-hak anak merupakan bagian dari hak asasi manusia yang tercantum dalam Undang-Undang dasar 1945 dan Konvensi Perserikatan Bangsa-Bangsa tentang hak-hak anak.

Pada tahun 2002, lahirlah Undang-Undang Nomor 23 tahun 2002 tentang Perlindungan Anak dengan pengesahannya yang dilakukan pada tanggal 22 Oktober 2002. Undang-Undang tersebut secara substansif telah mengatur tentang beberapa hal terkait perlindungan anak, seperti permasalahan anak yang sedang berhadapan dengan hukum, anak dari kelompok minoritas, anak korban eksploitasi ekonomi dan seksual, dan bentuk perlindungan anak lainnya.

Meskipun UndangUndang Nomor 23 tahun 2002 tentang Perlindungan Anak telah berlaku, namun seiring jalan, ditemukanlah beberapa aturan yang saling tumpang tindih dengan aturan sejenis. Ditambah 
lagi, tingkat kejahatan terhadap anak yang perlu mendapatkan perhatian lebih dari pemerintah.

\section{Untuk}

pengawasan

penyelenggaraan perlindungan anak menjadi lebih efektif, diperlukanlah dukungan lembaga independen yang dapat membantu pemerintah menyelenggarakan perlindungan anak. ditambah lagi, perlunya pemberatan sanksi atas pelaku kejahatan anak yang telah tertuang dalam Undang-Undang Nomor 23 tahun 2002 tentang Perlindungan Anak. Maka dari itu, pada tanggal 17 Oktober 2014, disahkanlah UndangUndang Nomor 35 tahun 2014 tentang Perlindungan Anak sebagai peraturan perundangundangan yang mengatur tentang penyelenggaraan perlindungan anak.

Menurut Siregar, aspek perlindungan anak lebih ditekankan pada hak hak anak bukan kepada kewajiban anak, karena anak secara hukum, anak belum dibebani kewajiban dan tidak dituntut pertanggungjawaban (Layyin Mafiana, 2014). Pada pelaksanaannya, perlindungan hukum pada anak tidak hanya didasari oleh hukum tertulis, tetapi juga didasari oleh hukum tidak tertulis yang hidup dalam masyarakat agar hak dan kewajiban anak dapat terjamin pelaksanaannya (Arif Gosita: 1985).

Pada dasarnya, pemerintah dan masyarakat harus bekerjasama untuk memenuhi hak-hak anak dan melindungi hak-hak tersebut. Pemenuhan perlindungan hak asasi anak merupakan langkah yang harus ditempuh dengan meletakkan hak anak ke dalam status sosial anak dalam kehidupan masyarakat, sebagai bentuk perlindungan terhadap kepentingan-kepentingan anak yang mengalami masalah sosial. Perlindungan tersebut dapat diberikan dengan cara yang sistematis melalui serangkaian program, stimulasi, latihan, pendidikan, bimbingan keagamaan, permainan, dan dapat juga diberikan melalui bantuan hukum yang dinamakan advokasi dan hukum perlindungan anak (Mafiana: 2014).

$$
\text { Pada pelaksanaan }
$$
perlindungan anak, orang tua memiliki peranan yang sangat penting dalam menjamin 
perlindungan terhadap anak. Untuk itu, mereka harus mendapatkan pendidikan dan pelatihan tata cara mendidik anak yang baik dan menghargai serta menjaga hak-hak anak. Pola asuh dengan menerapkan konsep pendidikan asah (orang tua harus mencerdaskan anak), asih (orang tua harus memberikan kasih sayang), dan asuh (orang tua harus mengarahkan anak) yang seimbang mutlak diperlukan.

\section{B. Dampak Dispensasi \\ Perkawinan}

Pada pemberian dispensasi perkawinan yang diajukan di Pengadilan Agama, pertimbangan hakim memberikan dispensasi perkawinan adalah maslahat bagi calon suami dan calon isteri yang masih di bawah umur (PA: 2017). Padahal, perkawinan dini pasca penetapan dispensasi perkawinan memiliki banyak dampak buruk, diantaranya adalah:

1. Perceraian dini

$$
\text { Pada penelitian yang }
$$

dilakukan oleh Muhammad Kunardi dan HM Mawardi Muzamil mengenai eksistensi perkawinan pasca pengajuan dispensasi perkawinan, ternyata perkawinan yang dilaksanakan ketika belum mencapai batas umur perkawinan yang ditentukan justru menjadi salah satu faktor perceraian bukan memberikan maslahat bagi perkawinan yang dilaksanakan. (Muhammad Kurniadi dan H.M. Mawardi Muzamil: 2014).

\section{Ekonomi}

Menurut Djamilah dan Reni Kartika, perkawinan anak sering kali melahirkan suatu siklus kemiskinan yang baru. Kondisi tersebut akan berlangsung secara turun temurun dari satu generasi ke generasi selanjutnya sehingga akan membentuk siklus kemiskina secara struktural. Hal ini terjadi hampir pada setiap kasus perkawinan anak (Djamilah dan Reni Kartika: 2014).

3. Sosial

Dalam hal sosial, perkawinan anak berpotensi atas terjadinya perceraian dan perselingkuhan pada pasangan muda yang baru melaksanakan perkawinan. Selain itu, ketika ada kasus anak remaja melaksanakan perkawinan karena kehamilan diluar perkawinan, maka pasangan muda tersebut akan kurang diterima (didiskriminasi) baik oleh keluarga sendiri 
maupun lingkungan sosialnya (Djamilah dan Reni Kartika: 2014).

\section{Kesehatan}

Melaksanakan perkawinan di usia muda memberikan risiko terhadap ketidaksiapan untuk melahirkan dan merawat anak. Selain itu terdapat kasus pecah rahim sehingga harus diangkat dan ekslamsi karena hamil di usia muda (Djamilah dan Reni Kartika: 2014).

Dan masih banyak dampak pelaksanaan pernikahan dini pasca dispensasi perkawinan. Dari dampak-dampak tersebut, tentu saja pelaksnaan perkawinan di usia anak pasca dispensasi perkawinan telah menciderai nilai-nilai pada pelaksanaan perlindungan anak di Indonesia.

\section{Yurisprudensi Dispensasi Perkawinan}

Dalam sebuah putusan atau penetapan oleh pengadilan terdapat satu bagian yang dikenal sebagai bagian pertimbangan, yaitu bagian yang dimulai dengan "Tentang Pertimbangan hukumnya atau Tentang Hukumnya". Pada bagian tersebut, terdapat beberapa hal yang dimuat, yaitu:
1. Gambaran tentang bagaimana hakim

mengkualifikasi, yaitu mencari dan menemukan hukum yang harus diterapkan pada suatu fakta dan kejadian yang diajukan.

2. Penilaian Hakim tentang fakta-fakta yang diajukan.

3. Pertimbangan Hakim secara kronologis dan rinci setiap item, baik dari pihak tergugat maupun penggugat.

4. Dasar hukum yang digunakan Hakim dalm menilai fakta dan memutus perkara, hukum tertulis maupun hukum tidak tertulis.

Dalam memberikan ketetapan, hakim harus mempertimbangkan berbagai hal untuk menentukan hukum. Hakim harus mempertimbangkan antara peraturan perundang-undangan yang ada dengan fakta-fakta yang diperoleh selama persidangan. Pada permohonan dispensasi perkawinan, hakim di Pengadilan Agama mempuyai beberapa pertimbangan, yaitu dalam menjatuhkan penetapan permohonan dispensasi perkawinan harus disesuaikan dengan hukum yang ada. Selain itu, hakim juga mempertimbangkan keterangan dari bukti- bukti 
M. Abdussalam Hizbullah

Eksistensi Dispensasi Perkawinan terhadap Pelaksanaan Perlindungan Anak Di

Indonesia

dan keterangan dari saksi-saksi (Intan Rif' atul Hakim: 2017).

Dalam menetapkan permohonan atau memutuskan perkara, penalaran hakim sangat dibutuhkan. Penalaran yang dilakukan oleh hakim sangat beragam tergantung pada argumentasi yang menjadi pertimbangannya. Penalaran yang dilakukan itu menuntut hakim untuk dapat berfikir yuridis mengikuti logikanya dalam menjalankan tugas profesionalnya (Hidayat: 2012).

Kemampuan berfikir yuridis yang dimaksud merupakan kemampuan hakim dalam melakukan penalaran hukum yang berlaku untuk dapat mengetahui dengan baik mengenai hak dan kewajiban dalam lingkungan pergaulan manusia untuk mewujudkan kepastian hukum, kemanfaatan sosial, dan keadilan di dalam masyarakat melalui penegakan kaidah-kaidah hukum (Hidayat: 2012).

Menurut Ziurani

Mahendra, Pertimbangan hakim Pengadilan Agama mengabulkan dispensasi perkawinan, didasari oleh 3 pertimbangan, yaitu :

1. Kelengkapan administrasi.
2. Tidak ada larangan perkawinan sebagaimana terdapat dalam Pasal 8 Undang-Undang No 1 Tahun 1974 Tentang Perkawinan.

3. Asas Kemaslahatan dan Kemudharatan.

Dikabulkannya

permohonan dispensasi perkawinan oleh pegadilan dianggap sangat diperlu-kan dalam kondisi yang sangat mendesak dengan harapan dapat memberikan manfaat yang besar bagi masyarakat. Dengan berbagai faktor yang ada hakim dianggap harus mengabulkan permohonan dispensasi perkawinan yang diajukan. Kondisi orang tua yang tidak mampu lagi mengontrol tingkah laku anak-anaknya adalah salah satu faktor pendorong untuk mengabulkan permohonan tersebut. Hakim harus mengabulkan permohonan dispensasi perkawinan demi kebaikan sang anak (Mahendra: 2014).

\section{Pengabulan}

atas permohonan dispensasi perkawinan dianggap akan memberikan kemudahan dan jalan keluar yang terbaik atas persoalan-persoalan yang terjadi dalam masyarakat. Alasan 
kuatnya adalah jika permohonan tersebut tidak dikabulkan, maka pihak orang tua akan merasa malu melihat anak-anaknya yang telah melakukan hubungan intim diluar perkawinan dan menyebabkan terjadinya kehamilan diluar perkawinan, sedangkan usia mereka masih dibawah umur yang ditetapkan Undang-Undang Nomor 1 tahun 1974 tentang Perkawinan. Ditambah lagi, pihak orang tua akan mendapatkan tekanan dan gunjingan dari orang-orang sekitar karena tidak mampu mendidik anaknya (Mahendra: 2014).

Dalam pertimbangannya, Majelis Hakim berpendapat bahwa pemberian dispensasi perkawinan ditujukan untuk menghindari ke-mudharat-an yang lebih besar harus didahulukan daripada menarik ke-maslahat-an. Kaidah fighiyyah yang digunakan adalah :

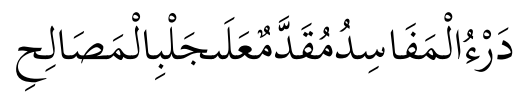

Artinya :

Menolak kerusakan harus didahulukan dari pada menarik kemaslahatan.

Menurut persepsi hakim, mudharat yang akan didapat jika tidak diberikan dispensasi perkawinan adalah ditakutkan jika anakanak pemohon tidak dikawinkan, maka akan menambah dosa dan terjadi perkawinan ilegal yang akan mengacaukan proses-proses hukum yang akan terjadi berikutnya atau mengacaukan hak-hak hukum anak yang dilahirkannya menurut undang-undang (Prabowo: 2013).

Dari ketetapan permohonan dispensasi perkawinan yang diberikan, seringkali hakim hanya fokus pada usia anak yang masih muda, tetapi tidak mempertimbangkan tingkat pendidikan dan pengetahuan anak yang masih rendah. Kemudian, ketetapan hakim tersebut tidak mempertimbangkan aturanaturan yang tertuang dalam undang-undang perlindungan anak. Ditambah lagi, hakim tidak mempertimbangkan isu-isu hukum internasional terhadap kepentingan anak (Hidayat: 2012).

Hakim juga tidak mempertimbangkan aspek pluralisme nilai-nilai hukum 
secara luas. Sangat sukar menarik batas antara nilai hukum internasional, transnasional, nasional dan lokal (adat) karena hukum berasal dari tataran yang berbeda-beda (Hidayat: 2012). Pada ketetapan dispensasi perkawinan yang telah dikabulkan oleh hakim, pertimbangan hukum yang dilakukan tidak memenuhi rasionalitas hukum, melainkan hanya memenuhi aspek hukum formil.

Pada ketetapannya, majelis hakim tidak memperhatikan kewajiban orang tua untuk mencegah terjadinya perkawinan di usia anak yang tertuang dalam Pasal 26 ayat 1 butir (c) Undang-Undang Nomor 35 tahun 2014 tentang Perlindungan Anak. Putusan yang tidak mempertimbangkan asasasas dan teori-teori hukum yang ada akan membuat konstruksi hukum menjadi tidak utuh. Teori hukum tidak bisa dilepaskan dari zamannya, teori tersebut harus dapat menjawab permasalahan hukum yang ada. Sehingga menuntut kepentingan secara luas. Oleh karena itu perlu kewaspadaan terhadap permasalahan hukum yang datang (Satjipto: 2006).

Ketetapan majelis hakim pada permohonan dispensasi perkawinan hanya mempertimbangkan aturanaturan yang tertuang pada Undang-Undang Nomor 1 tahun 1974 tentangPerkawinan, Kompilasi Hukum Islam, dan beberapa kaidah fiqh Islam. Majelis hakim tidak memperhatikan hak-hak anak yang harus dilindungi. Padahal, hak-hak yang dimiliki oleh seorang anak harus dijamin dan dilindungi. Atas ketetapannya, hakim tidak memperhatikan pertimbangan aspek kepentingan masa depan anak, baik dalam aspek pendidikan, kesehatan, akses kesamaan dalam mendapat peluang kerja, dan hal lainnya. Sehingga tidak ditemukan terobosan hukum untuk perlindungan kepentingan masa depan anak (Hidayat: 2012).

\section{Kedudukan Perlindungan Anak atas Dispensasi Perkawinan}


Dalam pembentukan perundang-undangan di Indonesia ada beberapa asas yang harus melekat dalam suatu undang-undang.Pada pasal 5 Undang-Undang nomor 12 tahun 2011 tentang Pembentukan Peraturan Perundang-Undangan, dijelaskan bahwa dalam membentuk peraturan perundang-undangan harus dibuat berdasarkan pada asas Pembentukan Peraturan PerUndang-Undangan yang baik, yaitu: kejelasan tujuan, kelembagaan atau pejabat pembentuk yang tepat, kesesuaian antara jenis, hierarki dan materi muatan, dapat dilaksanakan, kedayagunaan dan kehasilgunaan, kejelasan rumusan, dan keterbukaan.

Asas-asas tersebut harus dalam suatu peraturan perundang-undangan. Namun, dalam pelaksanaan penyimpangan usia yang diatur dalam pasal 7 ayat (2) UndangUndang perkawinan yang menjelaskan bolehnya memohon dispensasi perkawinan di Pengadilan Agama. Aturan tersebut tidak sesuai dengan asas kedayagunaan dan kehasilgunaan. Dimana suatu aturan dalam peraturan perundang-undangan dituntut dapat memberikan manfaat atau dampak baik dalam kehidupan masyarakat, bukan sebaliknya dengan memberikan dampak buruk dalam masyarakat.

Melihat dampak yang terjadi atas perkawinan di bawah umur pasca diberikannya dispensasi perkawinan oleh Pengadilan Agama, hal itu menunjukkan bahwa penyimpangan usia perkawinan ini tidak memberikan manfaat yang baik bagi masyarakat. Banyak sekali dampak buruk yang muncul, mulai dari perceraian dini, kelemahan ekonomi, kesehatan dalam keluarga, angka kematian ibu, angka kematian bayi, psikologi, sosial, hingga masalah-masalah lainnya.

Dengan kondisi tersebut, seharusnya dalam penegakan aturan (law enforcement) terkait dispensasi perkawinan ini harus mulai ditinggalkan secara perlahan. Aturan yang termuat dalam pasal 7 ayat (2) UndangUndang Perkawinan nomor 01 tahun 1974 harus dikesampingkan.

Pengenyampingan keberlakukan suatu aturan dalam undangundang itu dapat dilakukan oleh hakim dalam menggali dan 
M. Abdussalam Hizbullah

Eksistensi Dispensasi Perkawinan terhadap Pelaksanaan Perlindungan Anak Di

Indonesia

menetapkan suatu hukum. Atau justru aturan-aturan tersebut perlu dicabut dalam aturan perundang-undangan yang berlaku.

Kemudian, pada pasal 6 ayat (1) butir i Undang - Undang nomor 12 tahun 2011 tentang Pembentukan

Peraturan Perundang-Undangan, materi muatan yang ada dalam suatu aturan perundang-undangan harus pula mencerminkan asas ketertiban dan kepastian hukum.

Jika dikembalikan pada persoalan dispensasi perkawinan, pelaksanaannya akan membuat kebingungan pelaksanaan aturan karena pasal tersebut bertentangan dengan pasal 26 ayat (1) butir c UndangUndang perlidungan anak nomor 35 tahun 2014 yang mewajibkan orang tua untuk mencegah terjadinya perkawinan di usia anak. selain itu, dampak buruk yang ditimbulkan akibat perkawinan di bawah umur yang terjadi di masyarakat tidak membawa ketertiban di masyarakat. Aturan yang membolehkan dispensasi ini justru melanggar hak-hak yang dimiliki oleh seorang anak.

Dengan beberapa keadaan diatas, jelaslah bahwa pasal 7 ayat (2) Undang-Undang Perkawinan nomor 01 tahun 1974 yang mengatur tentang penyimpangan usia ini harus diuji kembali materi muatannya, kedayagunaan dan kehasilgunaan, pemberian kepastian hukum dan persamaan kedudukan di mata hukum serta asas-asas lain yang harus melekat dalam sebuah aturan dalam perundangundangan di Indonesia.

Selain asas-asas yang diatur dalam Undang - Undang nomor 12 tahun 2011 tentang Pembentukan Peraturan Perundang-Undangan, ada pula teori yang menjadi acuan dalam pembentukan peraturan perundang-undangan, salah satunya adalah asas Lex Specialis Derogat Lex Generalis.

Ketika merujuk pada asas lex specialis derogat lex generalis, dalam hal ini, yang menjadi frasa lexspecialis adalah UndangUndang Perlindungan Anak nomor 35 tahun 2014. Sedangkan Undang-Undang Perkawinan nomor 01 tahun 1974 merupakan frasa lexgeneralis.

Ketika membahas mengenai perkawinan di Indonesia, tentu UndangUndang Perkawinan nomor 01 
tahun 1974 menjadi rujukan utama yang dianggap menjadi dasar hukum dalam pelaksanaan perkawinan di Indonesia. mulai dari pengertian perkawinan, syarat-syarat hingga prosedurprosedur dalam pelaksnaan perkawinan.

Namun, dalam halnya dispensasi perkawinan yang berkaitan terhadap perlindungan anak, maka dalam menentukan dasar hukum pelaksanaannya, hendaknya juga mendahulukan undang-undang yang mengatur tentang perlindungan hak-hak anak, yaitu Undang-Undang Perlindungan Anak nomor 35 tahun 2014. Karena pada hakikatnya, aturan yang mengatur mengenai pelaksanaan perlindungan anak adalah Undang-Undang Perlindungan Anak nomor 35 tahun 2014. Oleh karena itu, perlulah untuk memperhatikan asas lex specialis derogat lex generalis.

Dari pembahasan di atas, dapat dilihat bahwa pada dasarnya, pelaksanaan dispensasi perkawinan tidak bisa mendegradasikan pelaksanaan perlindungan anak di Indonesia. Selain itu, mengingat dampak buruk pelaksanaan perkawinan usia anak pasca dispensasi perkawinan, tentu saja harus menjadi pertimbangan untuk mencegah terjadinya perkawinan usia anak pasca dispensasi perkawinan.

\section{Kesimpulan}

Mengingat kurang luasnya pertimbangan hakim pada pemberian dispensasi perkawinan dan dampak buruk yang diperoleh dari perkawinan di usia anak yang dilaksnaakan pasca dispensasi perkawinan, ditambah lagi dengan mempertimbangkan asas-asas peraturan perundang-undangan di Indonesia, maka peneliti memperoleh suatu kesimpulan bahwa pelaksanaan dispensasi perkawinan tidak dapat mendegradasikan pelaksanaan perlindungan anak di Indonesia.

Dengan kata lain, perlindungan anak di Indonesia sudah seyogyanya lebih diperhatikan untuk memastikan bahwa setiap anak dapat memperoleh hak-haknya secara utuh. Sedangkan aturan mengenai pelaksanaan dispensasi perkawinan harus dikaji lebih lanjut mengenai eksistensinya terhadap perlindungan anak di Indonesia agar pelaksanaannya tidak berbenturan dengan pelaksanaan perlindungan anak di Indonesia. 
M. Abdussalam Hizbullah

Eksistensi Dispensasi Perkawinan terhadap Pelaksanaan Perlindungan Anak Di

Indonesia

Saran peneliti atas penelitian ini adalah pelaksanaan perlindungan anak di Indonesia harus lebih diperhatikan untuk mencegah terjadinya hal-hal yang menciderai pelaksanaan perlindungan anak di Indonesia. Terutama bagi hakim Pengadilan Agama, seyogyanya mempertimbangkan perlindungan anak di Indonesia dalam memberikan dispensasi perkawinan.

\section{Daftar Pustaka}

Kamil, Ahmad dan Fauzan, Hukum Perlindungan dan Pengangkatan Anak Di Indonesia, (Jakarta: PT Raja Grafindo Persada, 2008).

Gosita, Arif. Masalah Perlindungan Anak, (Jakarta : Bina Aksara, 1985).

Djamilah dan Reni Kartikawati, "Dampak Perkawinan Anak Di Indonesia", Jurnal Studi Pemuda, III, (Mei, 2014).

Idayanti, Dwi. "Pemberian Dispensasi Menikah Oleh Pengadila Agama (Studi Kasus Di Pengadila Agama
Kota Mobagu)", Lex Privatum, II, (April, 2014)

Hardjono. Perlindungan Hukum Terhadap Anak, (Jakarta: Eresco, 2007).

Hakim, Intan Rif'atul. "Pertimbangan Hakim Terhadap Penetapan Dispensasi Kawin Di Pengadilan Agama Pacitan Pada Tahun 2016", (skripsi, fakultas syari'ah, institut agama islam negeri (IAIN) Ponorogo, Ponorogo, 2017).

Mahfiana, Layyin. "Perlindungan Hukum Terhadap Anak Di Era Globalisasi (Antara Ide dan Realita)", Justitia Islamica, X (Desember 2013).

Hidayat, Maya Yunita Sari "Pertimbangan Hukum Hakim Dalam Penetapan Dispensasi Perkawinan", Jurnal Ilmu Hukum Mizan, I, (Juni, 2012).

Miles, B. Mathew dan Michael Huberman. 1992. Analisis Data Kualitatif Buku Sumber Tentang Metode-metode Baru. Jakarta: UIP 
Kunardi, Muhammad dan HM Mawardi Muzamil, “Implikasi Dispensasi Perkawinan Terhadap Eksistensi Rumah Tangga Di Pengadila Agama Semarang", Jurnal Pembaharuan Hukum, I, (Agustus, 2014).

Satjipto, Rahardjo. Ilmu Hukum, (Bandung : PT. Citra Aditya bakti, 2006)

Fitriani, Rini. "Peranan Penyelenggara

Perlindungan Anak Dalam Melindungi Dan Memenuhi Hak-Hak Anak", Jurnal Hukum Samudra Keadilan, XI (Juli-Desember 2016).

Sudrajat, Tedy. "Perlindungan Hukum terhadap Hak Anak sebagai Hak Asasi Manusia, Kanun Jurnal Ilmu Hukum", Kanun Jurnal Ilmu Hukum, XIII, (Agustus, 2011).

Setiasih, Widihartati. "Analisis Putusan Dispensasi Nikah Di Bawah Umur Dalam Prespektif Perlindungan Perempuan", Jurnal PPKM, III, (Agustus, 2017).
Mahendra, Ziaurrani. "Pertimbangan Dan Faktor Penyebab Hakim Mengabulkan Permohonan Dispensasi Umur Perkawinan ( Studi Dalam Perpektif Pasal 7 Ayat 2 Undang-Undang Nomer 1 Tahun 1974 Dalam Periode 2011 Sampai Dengan 2013 Di Pengadila Agama Kota Malang)", Artikel Ilmiah Skripsi Universitas Brawijaya, 2014.

\section{Undang - Undang dan Yurisprudensi}

Ketetapan Pengadilan Agama Argamakmur tentang permohonan dispensasi perkawinan Nomor 0020/Pdt.P/2017/PA.AGM, 2017.

Undang-Undang nomor 23 tahun 2002 tentang Perlindungan Anak.

Undang-Undang nomor 35 tahun 2014 tentang Perlindungan Anak.

Undang-Undang nomor 1 tahun 1974 tentang Perkawinan 
M. Abdussalam Hizbullah

Eksistensi Dispensasi Perkawinan terhadap Pelaksanaan Perlindungan Anak Di

Indonesia

Undang-Undang Nomor 12

tahun 2011 tentang

Pembentukan Peraturan

Perundang-Undangan. 